\title{
Feeding habits and population aspects of the spotted goatfish, Pseudupeneus maculatus (Perciformes: Mullidae), on the continental shelf of northeast Brazil
}

\author{
Andrey Soares ${ }^{1}$, Alex Souza Lira ${ }^{1,2}$, Júlio Guazzelli Gonzalez ${ }^{1}$, Leandro Nolé Eduardo ${ }^{1,4}$, \\ Flávia Lucena-Frédou ${ }^{1}$, François Le Loc'h ${ }^{2}$, Beatrice Padovani Ferreira ${ }^{3}$, Thierry Frédou ${ }^{1}$

\footnotetext{
${ }^{1}$ Universidade Federal Rural de Pernambuco, Departamento de Pesca e Aquicultura, 52171-900, Recife, Brazil.

(AS) (Corresponding author) E-mail: andrey.soares@ufrpe.br. ORCID-iD: https://orcid.org/0000-0001-6742-6952 (ASL) E-mail: alex.lira@ufrpe.br. ORCID-iD: https://orcid.org/0000-0003-1734-1875

(JGG) E-mail: julio.gonzalez@ufrpe.br. ORCID-iD: https://orcid.org/0000-0002-8542-8852

(LNE) E-mail: leandronole@ hotmail.com. ORCID-iD: https://orcid.org/0000-0003-2369-4175

(FL-F) E-mail: flavia.fredou@ufrpe.br. ORCID-iD: https://orcid.org/0000-0001-5492-7205

(TF) E-mail: thierry.fredou @ufrpe.br. ORCID-iD: https://orcid.org/0000-0002-0510-6424 ${ }^{2}$ IRD, Univ Brest, CNRS, Ifremer, LEMAR, IUEM, F-29280 Plouzane, France.

(FLL) E-mail: francois.le.loch@ird.fr. ORCID-iD: https://orcid.org/0000-0002-3372-6997

${ }^{3}$ Universidade Federal de Pernambuco, Departamento de Oceanografia, 50670-901, Recife, Brazil. (BPF) E-mail: beatrice@ufpe.br. ORCID-iD: https://orcid.org/0000-0001-6315-9834 France.
} \\ ${ }^{4}$ Institut de Recherche pour le Développement (IRD), MARBEC (Université Montpellier, CNRS, Ifremer, IRD), Sète,
}

\begin{abstract}
Summary: This study provides information about the feeding habits, population aspects and spatial distribution of the spotted goatfish, Pseudupeneus maculatus, along the coast of the tropical Brazilian continental shelf. Distribution patterns are described using length frequencies and catch rates. Stable isotope ratios of carbon $\left(\delta^{13} \mathrm{C}\right)$ and nitrogen $\left(\delta^{15} \mathrm{~N}\right)$, along with stomach contents, were analysed to determine the diet of the spotted goatfish. Multivariate analysis and numerical indicators of the diet, such as numerical frequency, frequency of occurrence and weight percentage, were computed to evaluate the diet composition. The mean trophic position was defined using both stable isotope ratios and stomach content analysis. The length at first maturity for the species was determined as $13.7 \mathrm{~cm}$. A slight pattern in size distribution was observed, with mean size increasing with depth along the shelf. The diet was mainly composed of crustaceans, teleosts and Polychaeta. No clear dietary difference was found between habitat types, water depth or latitude. Both trophic positions estimated by stable isotopes and stomach contents analysis ranged between levels 3 and 4. P. maculatus was found to be feeding on many rare and infrequent prey items, classifying it as a generalist zoobenthivorous predator, probably due to its efficient search strategy.
\end{abstract}

Keywords: distribution patterns; stomach content analysis; Brazil; cross-shelf; stable isotopes.

Hábitos alimenticios y aspectos poblacionales del salmonete manchado, Pseudupeneus maculatus (Perciformes: Mullidae) sobre la plataforma continental del noreste de Brasil

Resumen: En este estudio se analizaron los hábitos alimenticios y aspectos biológicos del salmonete manchado (Pseudupeneus maculatus) frente a la costa brasileña. Para describir los patrones de distribución se analizó la estructura de tallas y las tasas de captura. El nivel trófico y la dieta alimenticia se determinaron mediante análisis isotópicos de carbono $\left(\delta^{13} \mathrm{C}\right)$ y nitrógeno $\left(\delta^{15} \mathrm{~N}\right)$, además del contenido estomacal. La composición de la dieta fue determinada con análisis multivariados e indicadores numéricos, como la frecuencia numérica, frecuencia de ocurrencia y el porcentaje del peso. Los resultados indicaron que la talla de primera madurez se encuentra en $13.7 \mathrm{~cm}$. Se observó que la talla media incrementó en relación con el fondo. Por otro lado, la dieta estuvo compuesta por crustáceos, teleósteos y poliquetos, asimismo no se evidenciaron diferencias significativas por tipo de hábitats, profundidad y grado de latitud. Los niveles tróficos estimados oscilaron entre 3 y 4 , determinándose que $P$. maculatus se alimentó de diversas presas, probablemente debido a su eficiente estrategia de búsqueda, clasificándose como depredador zoobentívoro generalista.

Palabras clave: patrones de distribución; análisis de contenido estomacal; Brasil; plataforma continental; isótopos estables.

Citation/Como citar este artículo: Soares A., Lira A.S., Gonzalez J.G., Eduardo L.N., Lucena-Frédou F., Le Loc'h F., Ferreira B.P., Frédou T. 2020. Feeding habits and population aspects of the spotted goatfish, Pseudupeneus maculatus (Perciformes: Mullidae), on the continental shelf of northeast Brazil. Sci. Mar. 84(2): 119-131. https://doi.org/10.3989/ scimar.04958.24A

Editor: P. Martín.

Received: May 29, 2019. Accepted: April 15, 2020. Published: May 4, 2020.

Copyright: () 2020 CSIC. This is an open-access article distributed under the terms of the Creative Commons Attribution 4.0 International (CC BY 4.0) License. 


\section{INTRODUCTION}

The spotted goatfish, Pseudupeneus maculatus, is an important fish resource on the continental shelf of northeast Brazil. This species is captured by small boats $(<10 \mathrm{~m}$ length) using box-like traps operating on the continental shelf in areas with rocky or gravel bottoms at depths varying between 15 and $30 \mathrm{~m}$ (Campos and Oliveira 2001, Lessa et al. 2004). Although this fishery occurs along the whole northeast region of Brazil, the commercial fishery that specifically targets this resource is almost entirely restricted to the states of Paraíba and Pernambuco. The spotted goatfish is one of the species most captured with traps in Pernambuco (Lessa et al. 2004, Ribeiro 2004), representing $11 \%$ of the total income stemming from fishery production in the northeast region of Brazil in 2006 (IBAMA 2008). This fish is also considered a highly valuable seafood compared with other categories of fishery resources, and is one of the few species captured by the artisanal fleet of Pernambuco that is destined for exportation (Marques and Ferreira 2010).

The biology of $P$. maculatus has been extensively studied. Various studies have investigated age and growth, length at first maturity, morphometry and feeding behaviour, having mostly relied on either underwater visual censuses or fishery-based data (Campos and Oliveira 2001, Krajewski et al. 2006, Filkovsky and Springer 2010). Though a considerable amount of information has been gathered, there remains a lack of large-scale studies on P. maculatus using fishery-independent data and linking the habitat type and physical characteristics to the stock distribution.

Studies of the diet and feeding activity of economically important species are important because they can provide valuable information on how the organisms' interactions with the environment contribute to ecosystem functioning and management, helping to identify potential marine protected areas (MPAs). Fishery management is subject to constant change and new concepts, as ecological studies on the spatial aspects of fish species are continually being carried out around the world (Douvere and Ehler 2009, Ehler 2013, Ehler et al. 2019). Such studies, especially those focusing on economically important species, are important because they may contribute to future management and conservation actions. This study aims to describe the population aspects, feeding habits and spatial distribution patterns of $P$. maculatus on the tropical Brazilian continental shelf with the intention of contributing to the development of future spatialized management.

\section{MATERIALS AND METHODS}

\section{Study area}

Sampling occurred along the northeastern coast of Brazil between the states of Rio Grande do Norte $\left(5^{\circ} \mathrm{S}\right)$ and Alagoas $\left(9^{\circ} \mathrm{S}\right)($ Fig. 1$)$. This region contains high biodiversity and several areas considered a priority for management and conservation (CBD 2014, Eduardo et al. 2018). The continental shelf is $40 \mathrm{~km}$ wide on average and almost completely covered by carbonate sediments (Vital et al. 2010), and the average depth varies between 40 and $80 \mathrm{~m}$ (Vital et al. 2010). This area holds many MPAs (e.g. APA Costa dos Corais, APA Guadalupe, APA Santa Cruz and APA Barra de Mamanguape) (Ferreira and Maida 2007, Prates et al 2007).
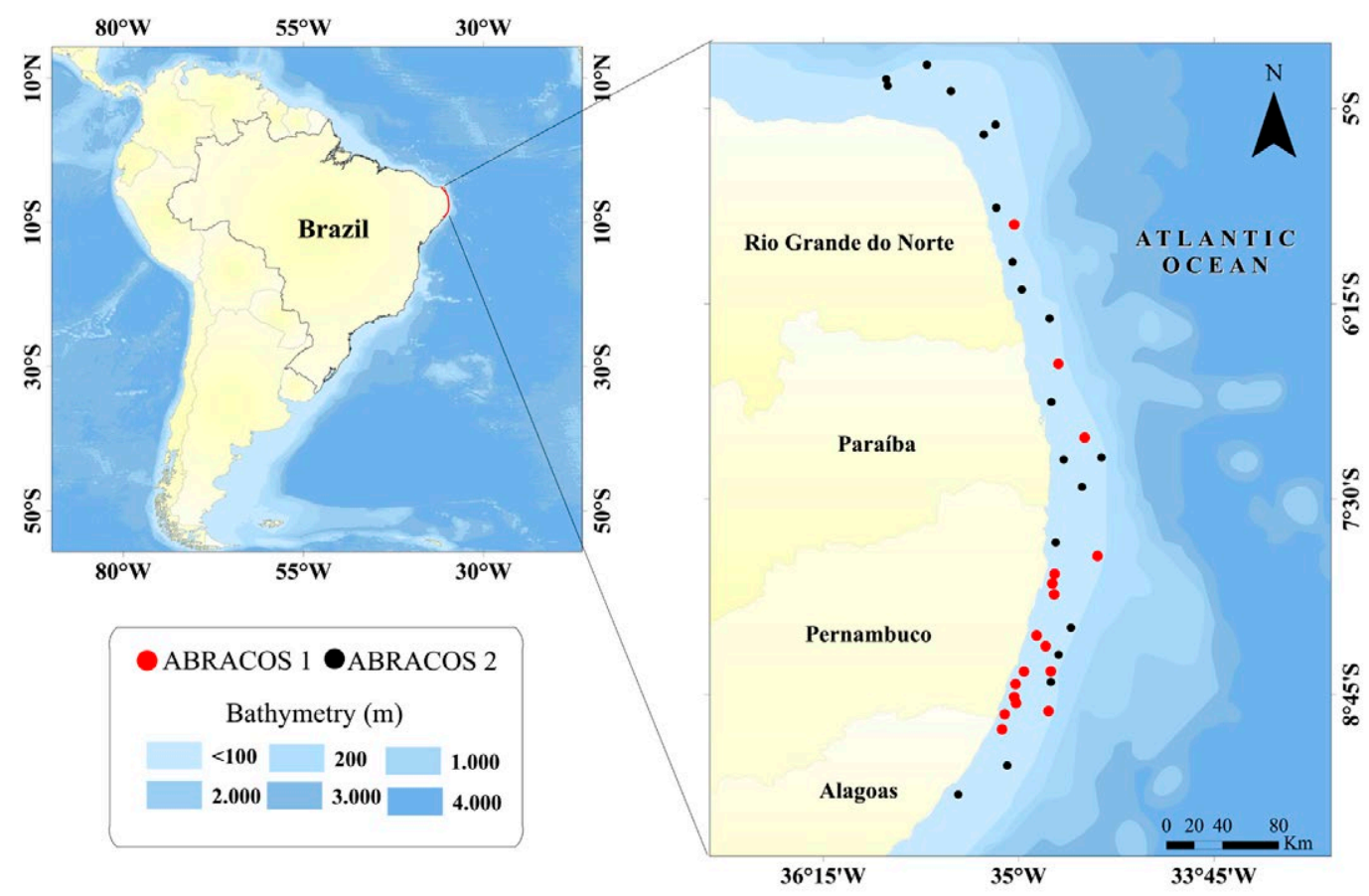

Fig. 1. - Study area with bathymetry and sample points along the continental shelf of the northeast coast of Brazil. Red dots indicate the first ABRACOS survey and black dots indicate the second ABRACOS survey. 


\section{Sampling and sample processing}

The samples were collected during the Acoustic Along Brazilian Coast (ABRACOS) project, carried out during two scientific expeditions (Bertrand 2015, 2017). The first expedition was carried out between $\mathrm{Au}-$ gust 2015 and September 2015 and the second between April 2017 and May 2017, both aboard the R/V Antea. There were 37 sampling stations along the transect of the continental shelf (Fig. 1). Trawls were performed at depths of between 10 and $60 \mathrm{~m}$ for 5 minutes with a bottom trawl net (body mesh $=40 \mathrm{~mm}$; cod-end mesh $=25 \mathrm{~mm}$; mouth aperture $=280 \mathrm{~m}^{2}$ ), with diurnal and nocturnal tows. The geometry of the net was evaluated through the SCANMAR system to give an estimate of its height, depth and aperture width. Temperature, salinity and oxygen profiles were collected for each haul using a Sea-Bird 911 CTD.

Three major types of habitat were identified and classified: (i) sand; (ii) algae; (iii) and sand with rocks, coralline formations and sponges (SWCR) (Eduardo et al. 2018). The $40 \mathrm{~km}$ average width of the continental shelf was used as the basis for classifying shelf position, according to the distance of the sampling point from the shore: inner-shelf $(<20 \mathrm{~km}$ from the shoreline) and outer-shelf ( $>20 \mathrm{~km}$ from the shoreline). Also, the latitudinal gradient was stratified in four levels according to the sampling point position: A $\left(<6^{\circ} \mathrm{S}\right), \mathrm{B}\left(6^{\circ} \mathrm{S}\right.$ to $\left.7^{\circ} \mathrm{S}\right), \mathrm{C}\left(7^{\circ} \mathrm{S}\right.$ to $\left.8^{\circ} \mathrm{S}\right)$ and $\mathrm{D}\left(>8^{\circ} \mathrm{S}\right)$; these levels were in accordance with Eduardo et al. (2018) for the same area. Onboard, each fish sample was identified, counted, weighed on a motion-compensating scale and preserved in a $4 \%$ formalin solution or frozen until further processing. In the laboratory, morphometric data were obtained for each specimen. Stomachs were removed through a ventral longitudinal incision and immediately fixed in $10 \%$ formalin solution for $48 \mathrm{~h}$, before being stored in a $70 \%$ alcohol solution. The contents of each stomach were sorted, counted, weighed $(\mathrm{g})$ and identified to the lowest possible taxonomic level.

\section{Population aspects and distribution patterns}

The length-weight relationship (LWR) was determined for grouped and separated sexes by using the log-transformed morphometric data collected in the laboratory. The relationship was expressed using the equation TW $=a \mathrm{SL} b$, where TW is the total weight in $\mathrm{g}, \mathrm{SL}$ is the standard length in $\mathrm{cm}, a$ the intercept (constant), and $b$ the regression slope (allometry coefficient). The allometry coefficients were further tested for significant deviations from the expected $b=3$ (Student $\mathrm{t}$-test). The condition factor $(\mathrm{K})$ was determined according to the method proposed by Ricker (1975) and adapted by Albieri and Araújo (2010), and was expressed using the equation

$$
\mathrm{K}=\frac{\mathrm{TW}}{\mathrm{SL}^{b}}
$$

where $b$ is the allometry coefficient of the LWR. The allometry coefficient and the condition factor were both tested for differences between habitats, shelf positions, latitude levels and sexes. The standard length was used because of the degradation of various individuals' tails. However, for purposes of comparison with other published studies that used fork length, the following equation is recommended: $\mathrm{FL}=0.136+1.062 \mathrm{SL}$.

Gonadal development was assessed by macroscopic evaluation and classified in four stages: A, immature; $\mathrm{B}$, maturing; $\mathrm{C}$, mature; and $\mathrm{D}$, spawned or resting. Length at first maturity $\left(\mathrm{L}_{50}\right)$ followed the King (2007) classification and was determined only for pooled sexes because of the low the number of sexed juveniles, which prevented the determination of sex and thus separation of the sexes. Sex ratio was determined as the total number of males/total number of females (Vazzoler 1996) and was statistically tested for significant deviations from the expected 1:1 ratio with a chi-squared test $(\alpha=0.05)$.

The relative index of biomass, defined as capture per unit of effort (CPUE), was determined on the basis of the number of fish captured per trawled area $(\mathrm{kg}$ $\mathrm{km}^{-2}$ ). The area was determined by multiplying the tow distance by the mouth opening area, estimated by the SCANMAR system. Additionally, possible influence of seasonal variables (e.g. temperature, salinity and dissolved oxygen) on the surveys was tested to assess its effects on the CPUEs but, although significant, the results did not show major differences between campaigns. Distribution patterns were evaluated through analysis of the length-frequency distribution and CPUE. To test significant differences in the mean standard length between shelf positions, habitats and latitude levels, the Kruskal-Wallis test was performed after the basic assumptions of normality, homoscedasticity and homogeneity were proven inadequate for a parametric test.

\section{Feeding habits and diet}

Feeding intensity was classified by observing the degree of fullness as follows: I, empty; II, partially empty; III, partially full; and IV, full (Viana et al. 2010). The Zavala-Camin (1996) fullness index (FI) was used as an indication of feeding intensity. FI differences between habitats, shelf position and latitude levels were tested using the Kruskal-Wallis test.

The contribution of each prey taxon to the diet composition was assessed by following three relative metrics of prey quantity: frequency of occurrence $(\% \mathrm{FO})$, numerical abundance $(\% \mathrm{~N})$ and weight percentage (\%W) (Hyslop 1980, Bowen 1996). All items collected in the stomach content analysis were considered for subsequent analyses. For a solid assessment of prey importance, two indexes were calculated: the index of relative importance (IRI) (Pinkas et al. 1971) and the alimentary index (IAi) (Kawakami and Vazzoler 1980), adapted by Oliveira et al. (2004). The IAi is based on frequency of occurrence and on the weight of each item. In contrast, the IRI combines the frequency of occurrence weight and numerical occurrence of each item. We chose to use these two indexes to have a more robust assessment of the diet. 
Niche breadth was estimated using Levin's standardized index $(B i)$. This index varies from 0 (species that feed on only one item) to 1 (species that feed on the same proportion of all evaluated items) (Levins 1968).

The feeding strategy was characterized using a modified Costello diagram (Amundsen et al. 1996), which is a graphic representation of prey items illustrating the degree of diet variability of a predator by plotting the prey-specific importance $(P i)$ of each prey taxon against the frequency of occurrence $(F o)$ in a $2 \mathrm{D}$ diagram.

To assess the degree of similarity in the diet, the multivariate technique of multidimensional scaling (nMDS) based on the Bray-Curtis similarity matrix was performed, with stomachs being considered as the sampling units. Relative weight of prey $(\% \mathrm{~W})$ was square root transformed to reduce any dominance effect of individual prey items. Differences between habitats, shelf position and latitude levels were tested through ANOSIM (Clarke 1993). The items that discriminated the groups were also evaluated using a SIMPER routine (Clarke 1993). The $\mathrm{R}$ software (R Core Team 2019) and the vegan package (Oksanen et al. 2019) were used for the multivariate analyses.

\section{Stable isotope analysis}

Up to ten individuals from each sampled station were selected for isotopic analysis. Fish had white muscular tissue extracted and cleaned with distilled water to remove exogenous material such as scales and bones. The samples were dried in an oven at $60^{\circ} \mathrm{C}$ for $48 \mathrm{~h}$ and ground into a fine powder with a mortar and pestle. Each sample was analysed for carbon and nitrogen isotope ratios through a mass spectrometer (Thermo Delta $\mathrm{V}+$ ) coupled with an element analyser (Thermo Flash 2000, interface Thermo ConFio IV) in the Platform Spectrometry Ocean (PSO; IUEM, France). Results of stable isotope analysis for carbon $\left(\delta^{13} \mathrm{C}\right)$ and nitrogen $\left(\delta^{15} \mathrm{~N}\right)$ are derived from the relation of the isotopic value from the sample and a known standard, $\delta^{13} \mathrm{C}$ or $\delta^{15} \mathrm{~N}=\left[\left(\mathrm{R}_{\text {sample }} / \mathrm{R}_{\text {standard }}\right)-1\right] \times 10^{3}$, in which $\mathrm{R}$ corresponds to the ratio between ${ }^{13} \mathrm{C}:{ }^{12} \mathrm{C}$ or ${ }^{15} \mathrm{~N}:{ }^{14} \mathrm{~N}$. The mean values of $\delta^{13} \mathrm{C}$ and $\delta^{15} \mathrm{~N}$ were tested for differences among habitats, shelf positions and along the latitude gradient. Also, the ontogenetic variation of $\delta^{13} \mathrm{C}$ and $\delta^{15} \mathrm{~N}$ isotopes was assessed across the continental shelf.

The trophic position of the spotted goatfish across habitats and shelf positions and along the latitudinal gradient was assessed using the formula proposed by Post (2002); TDF is the trophic discrimination factor and was considered to be $2.54 \%$ (Vanderklift and Ponsard 2003). As there was no long-living filter feeder to be the baseline, the mean $\delta^{15} \mathrm{~N}$ of zooplankton was used as a reference. Zooplankton community sampling was conducted at each station by horizontal haul with a bongo net, and the samples were organized into Eppendorf micro tubes and freeze-dried for at least 24 hours. To obtain the correct values from $\delta^{13} \mathrm{C}$, part of the samples was separated to remove the carbonates

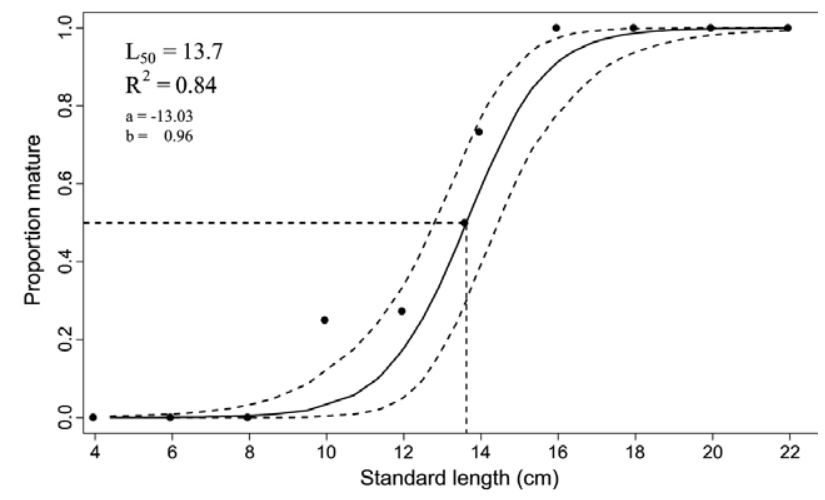

Fig. 2. - Standard length at first maturity $\left(\mathrm{L}_{50}, \mathrm{~cm}\right)$ and confidence intervals (CI, 95\%) for pooled sexes of spotted goatfish, P. maculatus, captured along the northeast Brazil coast.

$\left(\mathrm{CaCO}_{3}\right)$. Part of the sample was acidified according to Fry (1988) by adding hydrochloric acid $(\mathrm{HCl})$. After the procedure, the samples were redried at $60^{\circ} \mathrm{C}$ for 24 hours and homogenized, and subsamples were reanalysed.

To give a more robust representation of the trophic level, the trophic position based on the stomach content analysis was determined to compare with the results of the stable isotopes analysis, based on the methodology proposed by Adams et al. (1983).

\section{RESULTS}

\section{Population aspects and distribution patterns}

Of the 505 individuals captured and identified aboard, 291 were analysed in the laboratory. Standard length (SL) ranged from 4.4 to $23.8 \mathrm{~cm}$ $(15.05 \pm 4.01[$ mean \pm SD] $)$, while total weight $(\mathrm{TW})$ varied from 1.04 to $315.01 \mathrm{~g}(91.38 \pm 54.86)$. From these specimens, 154 gonads were in good enough condition to be retrieved, $28 \%$ being males, $34 \%$ females, and $38 \%$ juveniles whose gonads could not be sexed. In general, growth was classified as positively allometric $(b=3.20 ; \mathrm{p}<0.05)$, and the length at first maturity was estimated to be $13.7 \mathrm{~cm} \mathrm{SL}$ $(\mathrm{CI}=12.8-14.4)$ for the pooled sexes (Fig. 2). Significant differences in the allometric parameter were found between sexes, with females classified as negatively allometric $(b=2.75 ; \mathrm{p}<0.05)$ and males as isometric $(b=3.03 ; \mathrm{p}>0.05)$. When we compared the $b$ values within spatial categories, such as shelf positions and habitats, no significant differences were found. However, the $b$ values varied among latitude levels, being isometric in the $\mathrm{A}\left(<6^{\circ} \mathrm{S}\right)$ and $\mathrm{B}$ ( 6 to $7^{\circ} \mathrm{S}$ ) strata and positively allometric in the $\mathrm{C}$ (7 to $\left.8^{\circ} \mathrm{S}\right)$ and $\mathrm{D}\left(>8^{\circ} \mathrm{S}\right)$ strata.

Overall, females and males were equally abundant $(1: 1)$, with no significant differences in the sex ratio $(\mathrm{p}>0.05)$. The most representative size class was 16$18 \mathrm{~cm}$, comprising $29 \%$ of the individuals. Females were most frequent at lower sizes, with their most representative size class being $16-18 \mathrm{~cm}$; males, mostly represented in the $18-20 \mathrm{~cm}$ size class, were most frequent at larger sizes (Fig. 3). Most individuals with sex 

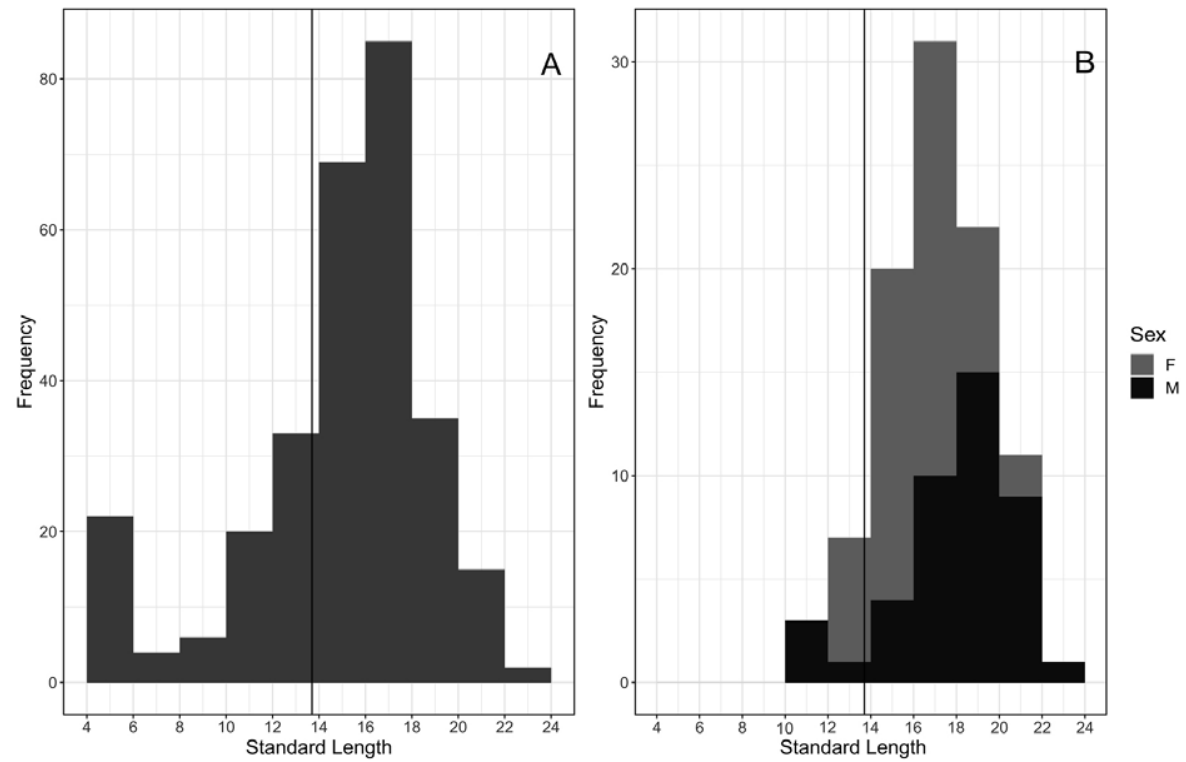

Fig. 3. - Length-frequency distribution of pooled (A) and separated sexes $(\mathrm{N}$ females $=52 ; \mathrm{N}$ males $=43)(\mathrm{B})$ of $P$. maculatus. The vertical black line indicates the size at first maturity $\left(\mathrm{L}_{50}=13.7\right)$.
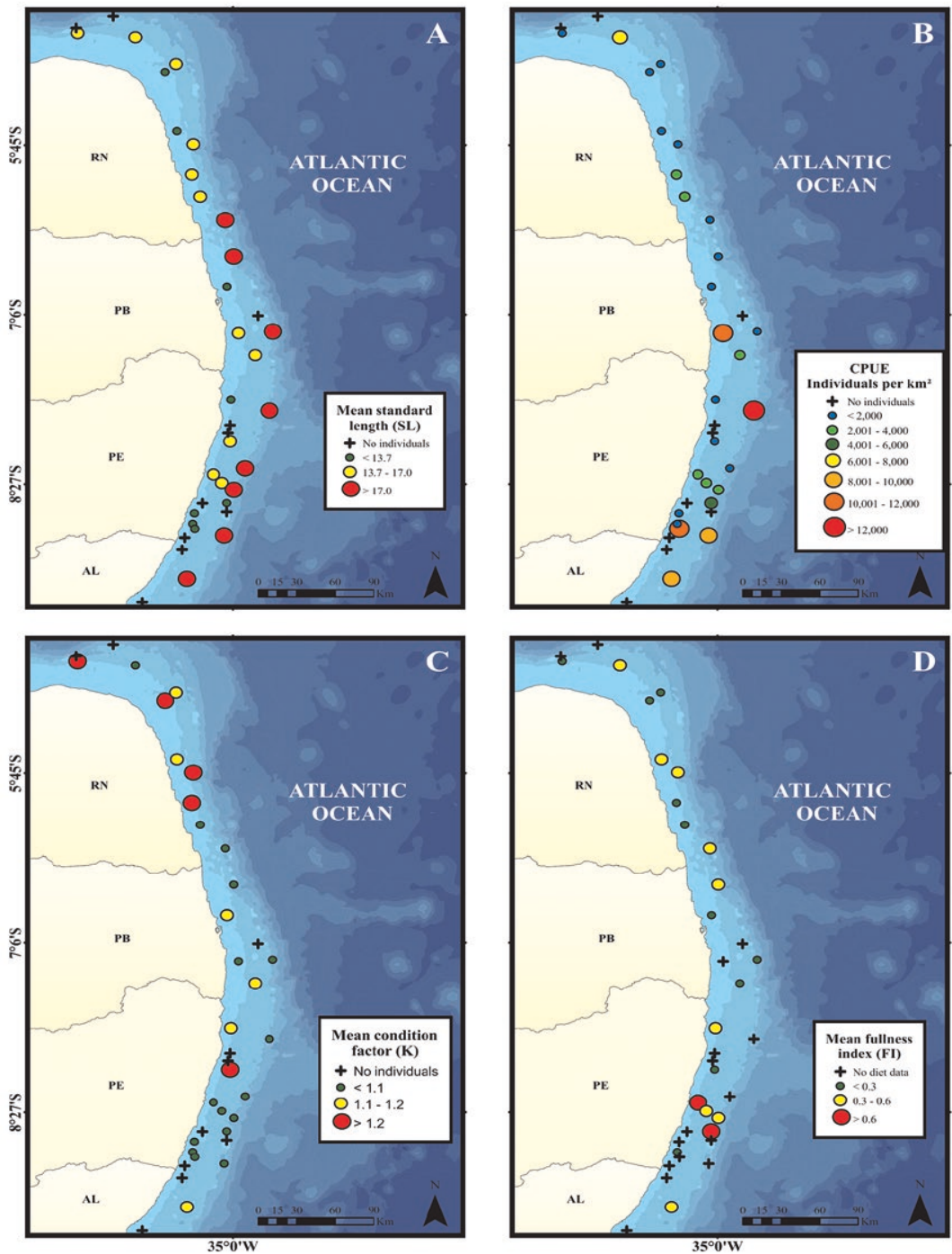

Fig. 4. - Spatial representation of mean standard length (A), catch per unit effort (B), mean condition factor (C) and mean fullness index (D) of $P$. maculatus distributed along the sampling points on the continental shelf of northeast Brazil. 

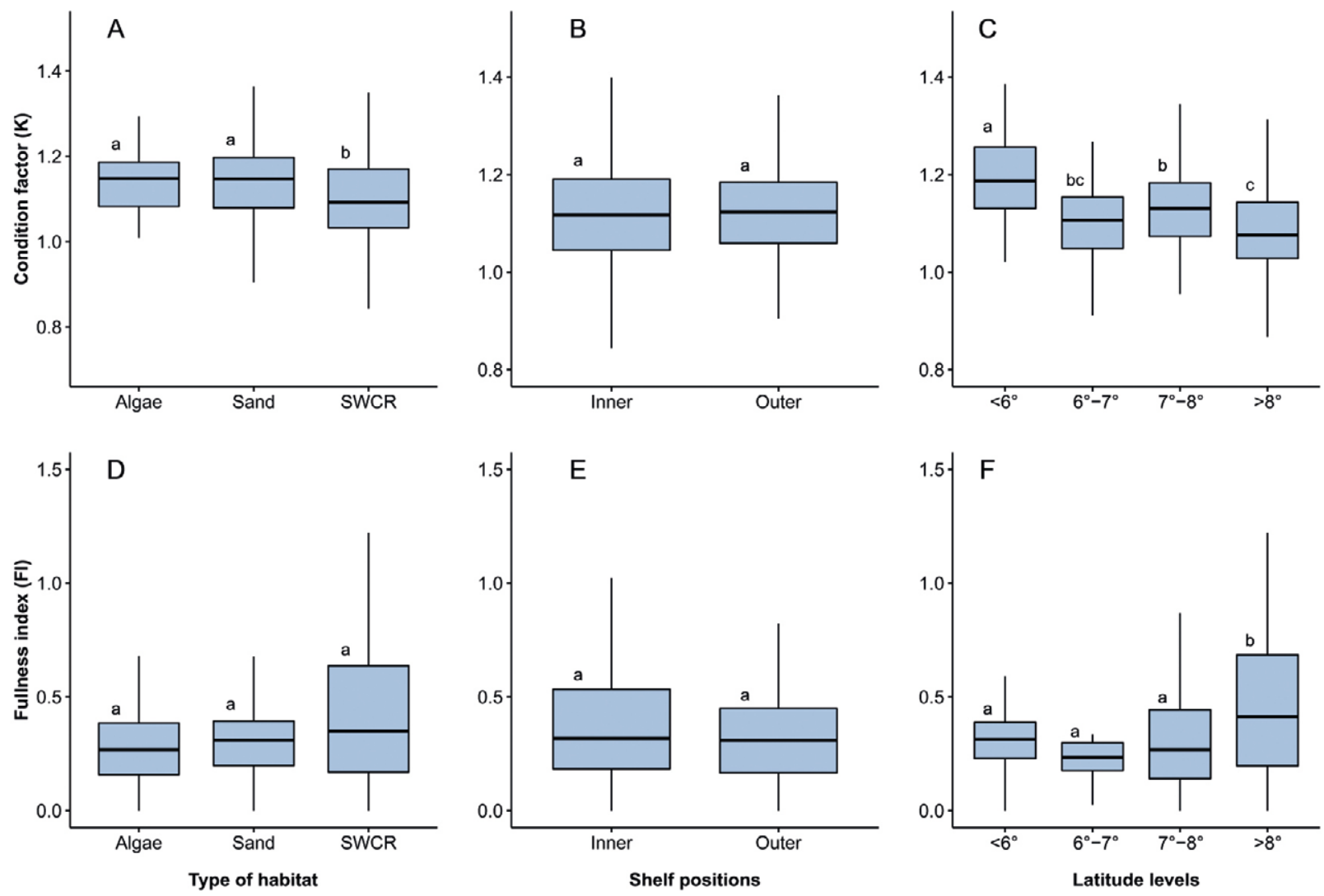

Fig. 5. - Condition factor (K) and fullness index values (FI) of P. maculatus in different habitats, latitude levels and shelf positions. The black horizontal line and box represent the median value and the interquartile range, while the vertical lines represent the upper and lower limits. Outliers were not included in the plot. Different letters mean significant difference.

identified were adults $(90.6 \%$ adult males and $90.3 \%$ adult females). Differences in size frequency distribution were found between SWCR and the other habitats, with a high presence of juveniles in SWCR. Despite this higher prevalence of juveniles, the mean SL in SWCR was higher than that in other habitats due to the bimodal distribution characterized by a high frequency of juveniles and larger individuals (SL>17 cm) and a large range of lengths. Mean SL and size distribution were higher in outer-shelf than inner-shelf areas $(\mathrm{p}<0.05)$ (Fig. 4A).

No significant differences in mean SL were found among the latitude levels, however, at stratum D a high frequency of juveniles was found. The CPUE analysis (Fig. 4B) revealed higher abundance of individuals at the southern sampling points (below $8^{\circ} \mathrm{S}$ ). There were also some abundance peaks off the coast of Pernambuco and Paraíba, where fisheries for spotted goatfish are present, and off the northern Rio Grande do Norte coast.

Significant differences in the condition factor $(\mathrm{K})$ were identified among habitats, with SWCR showing lower values than the other habitats $(\mathrm{p}<0.05)$ (Fig. 5A). Significant differences in K were also identified among latitude strata (Fig. 5C), with the northernmost areas $\left(<6^{\circ} \mathrm{S}\right)$ presenting higher values than other areas $(\mathrm{p}<0.05)$, while the southernmost stratum exhibited the lowest $\mathrm{K}$ values $(\mathrm{p}<0.05)$ (Fig. 4C). No statistical differences in $\mathrm{K}$ were found between shelf positions and sexes.

\section{Diet composition}

A high proportion of $P$. maculatus had food contents in their stomach (degrees II, III and IV) (63\%), mainly those found in algae (88\%) and SWCR $(85 \%)$ habitats, whereas the proportion of those inhabiting sand with food in their stomach was considerably lower $(56 \%)$. Also, $65 \%$ of those fish with no stomach content (degree I) were captured at night-time. Of those with food content in their stomach, only $20 \%$ were collected during night tows, and $85 \%$ of these night tows were performed earlier than $9 \mathrm{pm}$. There was no significant difference $(p>0.05)$ in FI between habitats and shelf positions (Fig. 4D), but differences were found between latitude stratum D and the other levels $(\mathrm{p}<0.05)$ (Fig. 4F).

The diet of $P$. maculatus was composed mainly of crustaceans, teleosts and Polychaeta. In general, crustaceans dominated over the other food categories, especially the decapods, which were the most abundant. The most frequent items were unidentified shrimp, Polychaeta and teleosts $(\% \mathrm{FO}=34,20$ and 17, respectively). Among decapods, shrimps $(\% \mathrm{FO}=45)$ dominated, followed by Brachyura $(\% \mathrm{FO}=13)$ (Table 1$)$. Unidentified shrimp were the most abundant in number $(\% \mathrm{~N}=31)$, followed by Caridea shrimp $(\% \mathrm{~N}=18)$, Polychaeta and teleosts $(\% \mathrm{~N}=10$ each), whereas teleosts had the highest biomass of the food groups $(\% \mathrm{~W}=28)$, followed by shrimps and Polychaeta $(\% \mathrm{~W}=23$ and 7 , respectively) (Table 1). In general, crustaceans were 
Table 1. - Contribution of each prey item for the overall diet of $P$. maculatus by frequency of occurrence $(\% \mathrm{FO})$, number $(\% \mathrm{~N})$ and weight $(\% \mathrm{~W})$. (UOM*, unidentified organic matter; UI, unidentified).

\begin{tabular}{|c|c|c|c|}
\hline Prey items & \multicolumn{3}{|c|}{$\mathrm{n}=193$} \\
\hline Crustacea & & - & - \\
\hline UI & 17.10 & - & 15.21 \\
\hline Decapoda & 58.55 & & 26.73 \\
\hline Brachyura & 032 & & 250 \\
\hline $\begin{array}{l}\text { UI } \\
\text { Callapa sp. }\end{array}$ & $\begin{array}{l}9.32 \\
1.04\end{array}$ & $\begin{array}{l}3.66 \\
0.29\end{array}$ & $\begin{array}{l}2.50 \\
0.34\end{array}$ \\
\hline Callinectes sp. & 3.11 & 1.17 & 1.06 \\
\hline Shrimp & 45.08 & 53.15 & 22.84 \\
\hline UI & 34.20 & 31.19 & 14.18 \\
\hline Caridea & 7.77 & 18.45 & 4.59 \\
\hline Penaeidae & 3.11 & 3.51 & 4.07 \\
\hline Rincopenaeus constrictus & 0.52 & 0.73 & 0.07 \\
\hline Stomatopoda & 14.51 & 7.03 & 6.75 \\
\hline Isopoda & & & \\
\hline UI & 2.07 & 0.88 & 0.68 \\
\hline Aegidae & & & \\
\hline Rocinela signata & 1.04 & 0.29 & 0.14 \\
\hline $\begin{array}{l}\text { AImpinpoda } \\
\text { UI }\end{array}$ & 3.63 & 190 & 0.03 \\
\hline Gammaridea & 1.04 & 1.46 & 0.01 \\
\hline Ostracoda & 4.66 & 3.07 & 0.06 \\
\hline Teleostei & & & \\
\hline UI & 16.06 & 10.54 & 27.29 \\
\hline Ballistidae & 0.52 & 0.15 & 0.40 \\
\hline Singnathidae & 1.04 & 0.29 & 0.10 \\
\hline Mollusca & 2.07 & 0.44 & 1.37 \\
\hline Gastropoda & 1.55 & 0.29 & 0.00 \\
\hline Cephalopoda & & & \\
\hline Macrotritopus defilippi & 0.52 & 0.15 & 1.37 \\
\hline Echinodermata & 0.52 & 0.15 & 0.04 \\
\hline Annelida & & & \\
\hline Polychaeta & & & \\
\hline UI & 13.47 & 6.44 & 4.00 \\
\hline Dorvilleidae & 1.04 & 0.29 & 0.03 \\
\hline Eunicidae & 3.63 & 2.64 & 2.21 \\
\hline Oenonidae & 0.52 & 0.15 & 0.21 \\
\hline Opheliidae & 1.04 & 0.29 & 0.04 \\
\hline Sabellariidae & 2.07 & 0.73 & 0.50 \\
\hline $\mathrm{UOM}^{*}$ & 16.06 & - & 7.65 \\
\hline Detritus & 9.84 & - & 2.26 \\
\hline
\end{tabular}

Table 2. - Ranking of importance of each category of prey item identified in the stomach content of $P$. maculatus according to each importance index.

\begin{tabular}{ccc}
\hline Rank & Index of relative importance & Alimentary index \\
\hline 1 & Shrimps & Shrimps \\
2 & Teleostei & Teleostei \\
3 & Polychaetas & Polychaetas \\
4 & Stomatopoda & Stomatopoda \\
5 & Brachyura & Brachyura \\
\hline
\end{tabular}

the most important food group found in P. maculatus, followed by teleosts and Polychaeta (Table 2).

The largest niche breadth was observed for outershelf over inner-shelf habitats $(B i=0.44$ and 0.39 respectively) and, among habitat types, algae showed a higher value than sand and SWCR $(B i=0.50,0.37$ and 0.36 respectively).

According to the modified Costello diagram (Fig. 6), no specific species was preferentially targeted by $P$. maculatus. Instead, considering the vertical axis, most prey are on the left side of the diagram, with a low frequency of occurrence $(F o)$. Considering prey importance, the diet of $P$. maculatus consisted mostly

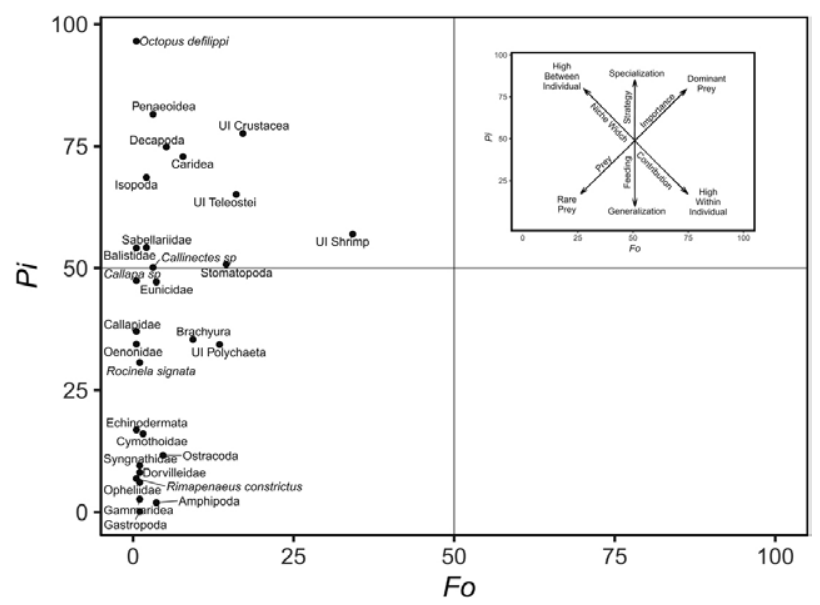

Fig. 6. - Modified Costello diagram (Pi, prey specific abundance; $\mathrm{Fo}$, frequency of occurence), a scatterplot containing all prey items, showing the feeding strategy of $P$. maculatus captured along the northeast coast of Brazil. On the top right, the explanatory axes for foraging patterns are those of Costello (1990), as modified from Amundsen et al. (1996).

of rare prey taxa present in small proportions (low $\mathrm{Fo} /$ $P i)$. Other items were also not often seen but had a high contribution in weight when present, such as isopods, stomatopods and teleosts. Based on the position of the items relative to the diagonal axis from top-left to bottom-right, the niche breadth is mostly due to a high between-phenotype component. The spotted goatfish seemed to be a generalist predator, feeding on many rare prey taxa. On the other hand, the population had some individuals with some degree of specialization that fed substantially on infrequent prey (high $P i$ and low $F o$ ).

The arrangement obtained by the multidimensional analysis (nMDS) showed a high overlap of the diet between habitats (Fig. 7A), with very weak, although significant, differences (ANOSIM: $\mathrm{R}=0.04 ; \mathrm{p}<0.05$ ).

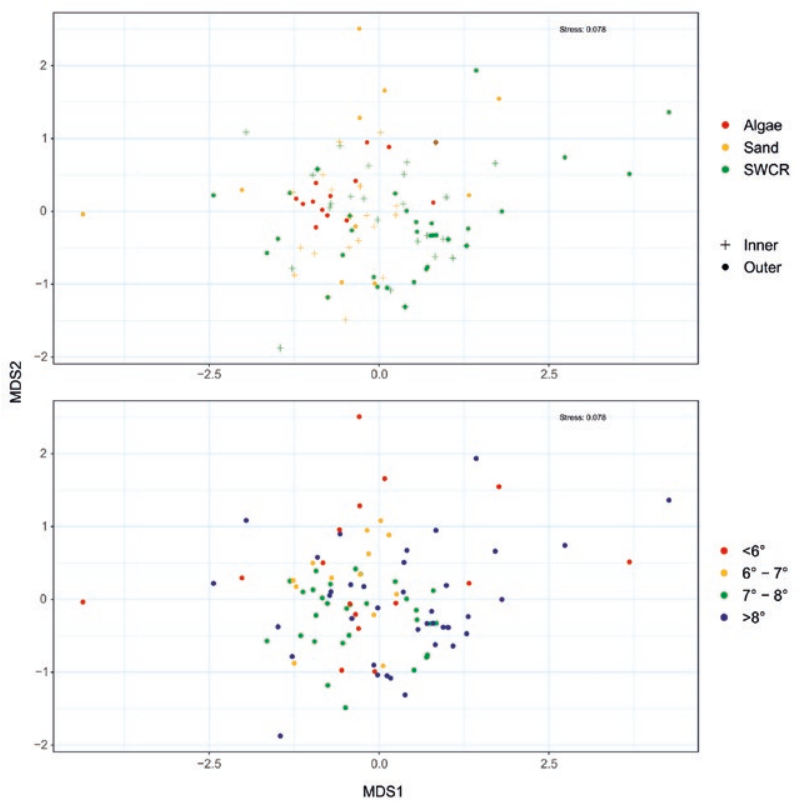

Fig. 7. - nMDS plot of the feed composition of $P$. maculatus in the different habitats (A - colours), shelf positions (A - shapes) at the different levels of latitude (B). 
$126 \cdot$ A. Soares et al.

Table 3. - SIMPER analysis: breakdown of average similarity within groups of habitats (SWCR; sand; algae), shelf position (inner and outer) and latitude levels $\left(\mathrm{A},<6^{\circ} \mathrm{S} ; \mathrm{B}, 6 \sim 7^{\circ} \mathrm{S} ; \mathrm{C}, 7 \sim 8^{\circ} \mathrm{S} ; \mathrm{D},>8^{\circ}\right)$ and the contribution of each prey item in the diet of $P$. maculatus.

\begin{tabular}{|c|c|c|c|c|c|}
\hline & Av. Abund & Av. Sim & $\mathrm{Sim} / \mathrm{SD}$ & Contrib \% & Cum. \% \\
\hline \multicolumn{6}{|c|}{ Group SWCR } \\
\hline UI shrimp & 2.93 & 7.60 & 0.36 & 43.68 & 43.68 \\
\hline UI Teleostei & 2.12 & 3.47 & 0.25 & 19.95 & 63.63 \\
\hline UI Crustacea & 1.99 & 3.28 & 0.22 & 18.87 & 82.50 \\
\hline \multicolumn{6}{|c|}{ Group Sand } \\
\hline UI Crustacea & 3.79 & 11.74 & 0.45 & 53.76 & 53.76 \\
\hline UI shrimp & 2.74 & 6.54 & 0.33 & 29.94 & 83.70 \\
\hline \multicolumn{6}{|c|}{ Group Algae } \\
\hline UI Crustacea & 6.57 & 35.55 & 0.96 & 93.97 & 97.97 \\
\hline \multicolumn{6}{|l|}{ Group Inner } \\
\hline UI Crustacea & 4.15 & 14.39 & 0.50 & 59.01 & 59.01 \\
\hline UI shrimp & 2.54 & 5.67 & 0.32 & 23.25 & 82.27 \\
\hline \multicolumn{6}{|c|}{ Group Outer } \\
\hline UI shrimp & 2.44 & 5.30 & 0.29 & 35.30 & 43.68 \\
\hline UI Crustacea & 2.52 & 5.22 & 0.28 & 34.72 & 70.02 \\
\hline \multicolumn{6}{|l|}{ Group A } \\
\hline UI shrimp & 3.58 & 11.38 & 0.40 & 54.63 & 54.63 \\
\hline Caridea & 2.44 & 5.16 & 0.25 & 24.79 & 79.42 \\
\hline \multicolumn{6}{|c|}{ Group B } \\
\hline UI Crustacea & 6.68 & 38.65 & 0.97 & 91.96 & 91.96 \\
\hline \multicolumn{6}{|c|}{ Group C } \\
\hline UI Crustacea & 4.19 & 14.28 & 0.51 & 60.06 & 60.06 \\
\hline UI shrimp & 2.41 & 5.24 & 0.32 & 22.04 & 82.11 \\
\hline \multicolumn{6}{|c|}{ Group D } \\
\hline \multicolumn{6}{|c|}{ Average similarity: 14.60} \\
\hline UI shrimp & 2.26 & 4.38 & 0.31 & 30.02 & 30.02 \\
\hline UI Teleostei & 1.97 & 2.90 & 0.23 & 19.89 & 49.91 \\
\hline UI Crustacea & 1.83 & 2.57 & 0.19 & 17.63 & 67.54 \\
\hline Stomatopoda & 1.79 & 2.53 & 0.20 & 17.30 & 84.84 \\
\hline
\end{tabular}
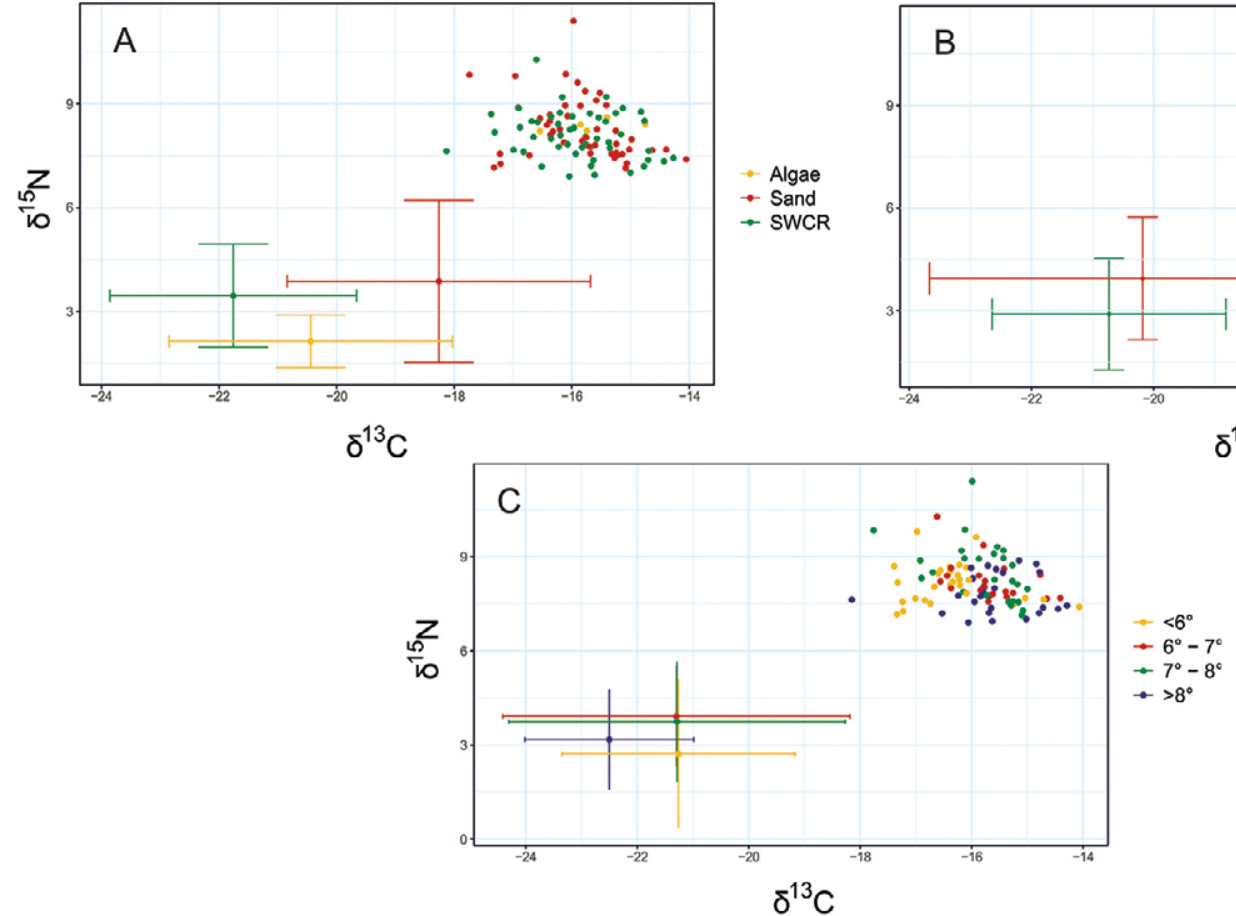

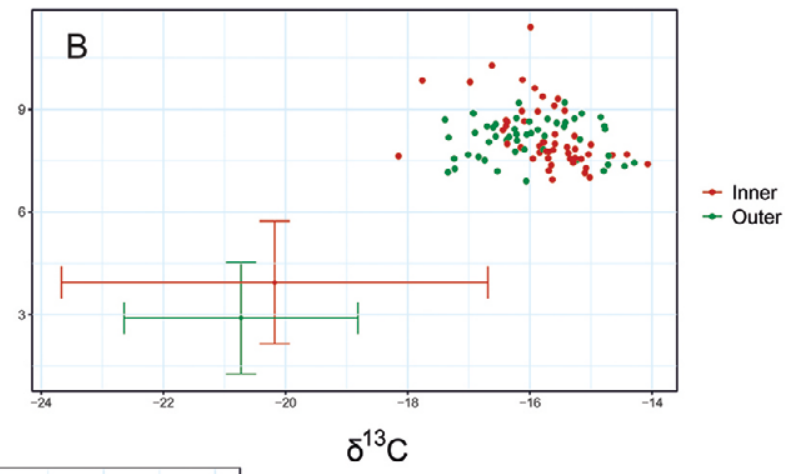

Fig. 8. $-\delta^{13} \mathrm{C}$ and $\delta^{15} \mathrm{~N}$ values of $P$. maculatus. Colours represent different levels of habitat (A), shelf position (B) and latitude gradient (C). $\delta^{13} \mathrm{C}$ and $\delta^{15} \mathrm{~N}$ signatures of zooplankton are also shown (mean $\left.\pm \mathrm{SD}\right)$. 


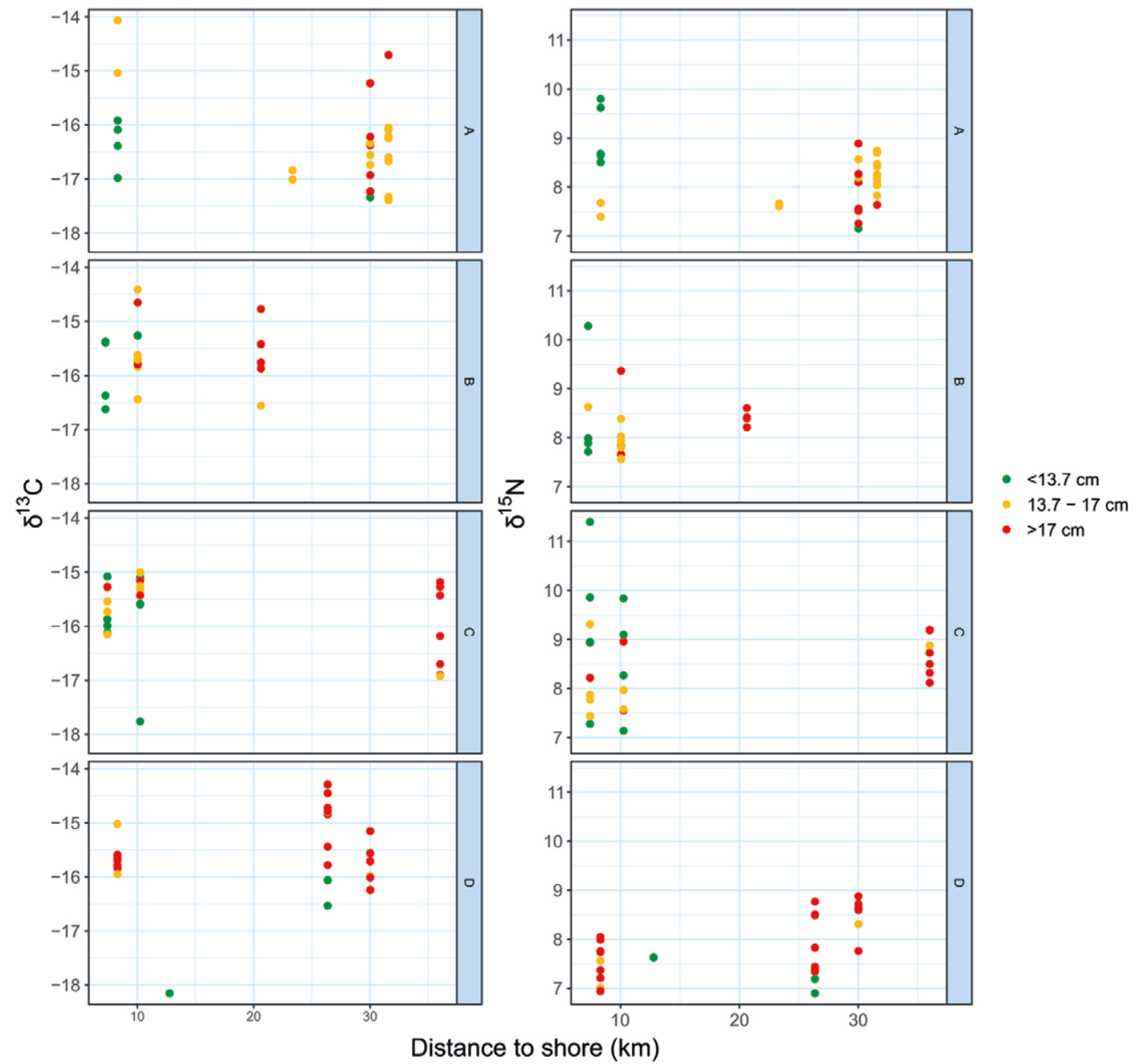

Fig. 9. $-\delta^{13} \mathrm{C}$ and $\delta^{15} \mathrm{~N}$ values of $P$. maculatus along the latitude gradient and across the continental shelf $\left(\mathrm{A},<6^{\circ} \mathrm{S} ; \mathrm{B}, 6 \sim 7^{\circ} \mathrm{S} ; \mathrm{C}, 7 \sim 8^{\circ} \mathrm{S} ; \mathrm{D}\right.$, $>8^{\circ}$ ). Letters represent longitude gradient while colours represent different size classes.

Also, weak significant differences in diet were detected between shelf positions (Fig. 7A) (ANOSIM: $\mathrm{R}=0.02$; $\mathrm{p}<0.05)$ and between latitude strata (Fig. 7B) (ANOSIM: $\mathrm{R}=0.06 ; \mathrm{p}<0.05)$. The SIMPER routine indicated that mainly shrimps, stomatopods and teleosts contributed to the similarity within habitats, shelf positions and latitude levels (Table 3).

\section{Stable isotopes analysis}

A total of $101 P$. maculatus muscle samples were analysed for stable isotope composition $\left(\delta^{13} \mathrm{C}\right.$ and $\left.\delta^{15} \mathrm{~N}\right)$. The SL of the individuals selected varied between 6.8 and $23.8 \mathrm{~cm} 15.91 \pm 3.16$ (mean $\pm \mathrm{SD})$. The values for $\delta^{13} \mathrm{C}$ ranged from -18.15 to $14.07 \%$, and $\delta^{15} \mathrm{~N}$ varied from 6.9 to $11.4 \%$. Significant differences were found in $\delta^{15} \mathrm{~N}$ along the latitudinal gradient. Kruskal-Wallis tests revealed differences in $\delta^{15} \mathrm{~N}$ only between strata $\mathrm{D}$ and $\mathrm{C}(\mathrm{p}<0.05)$. Significant differences were also found in $\delta^{13} \mathrm{C}$ along the latitude gradient, with stratum A showing lower values than the other strata $(\mathrm{p}<0.05)$. There were no significant differences in $\delta^{13} \mathrm{C}$ and $\delta^{15} \mathrm{~N}$ among habitats and shelf positions $(\mathrm{p}<0.05)$, and these values were not correlated with size $(\mathrm{SL})\left(\mathrm{R}^{2}=0.15\right)$. As values of $\delta^{13} \mathrm{C}$ and $\delta^{15} \mathrm{~N}$ varied greatly, any model approach was designed to fit the data. The $\delta^{13} \mathrm{C}$ and $\delta^{15} \mathrm{~N}$ values of the isotopic baseline (zooplankton) were also evaluated and compared between habitat, shelf position and latitude gradient, and no statistical significances were detected (Fig. 8). Also, no ontogenetic or crossshelf distribution pattern of $\delta^{13} \mathrm{C}$ and $\delta^{15} \mathrm{~N}$ isotopes was identified (Fig. 9).

Table 4. - Trophic position of $P$. maculatus estimated through stable isotopes $\left(\mathrm{TP}_{\mathrm{SI}}\right)$ and its upper and lower limits and stomach content analysis $\left(\mathrm{TP}_{\mathrm{SC}}\right)$ in different habitats, shelf positions and latitude gradient $\left(\mathrm{A},<6^{\circ} \mathrm{S} ; \mathrm{B}, 6 \sim 7^{\circ} \mathrm{S} ; \mathrm{C}, 7 \sim 8^{\circ} \mathrm{S} ; \mathrm{D},>8^{\circ}\right)$.

\begin{tabular}{lcccc}
\hline & Mean $\mathrm{TP}_{\mathrm{SI}}$ & Lower limit & Upper limit & $\mathrm{TP}_{\mathrm{SC}}$ \\
\hline Habitat & & & & \\
\hline Algae & 3.84 & 3.58 & 4.11 & 3.75 \\
Sand & 3.30 & 2.87 & 3.75 & 3.50 \\
SWCR & 3.37 & 3.12 & 3.62 & 3.56 \\
Shelf pos. & & & & \\
Inner & 3.25 & 2.96 & 3.54 & 3.52 \\
Outer & 3.54 & 3.31 & 3.81 & 3.57 \\
Lat. grad. & & & & \\
A & 3.61 & 3.26 & 3.99 & 3.52 \\
B & 3.28 & 2.99 & 3.58 & 3.59 \\
C & 3.41 & 3.08 & 3.76 & 3.40 \\
D & 3.36 & 3.16 & 3.57 & 3.27 \\
\hline
\end{tabular}


Overall, the trophic level of the spotted goatfish was between the third and fourth position, classifying it as a carnivore predator. The effects of habitat, shelf position and latitude gradient were virtually non-existent. The results of the trophic position analysis based on the diet $\left(\mathrm{TP}_{\mathrm{SC}}\right)$ were very close to the results provided by the isotopic analysis $\left(\mathrm{TP}_{\mathrm{SI}}\right)$ (Table 4$)$.

\section{DISCUSSION}

This work was the first study on feeding habits including isotopic analysis for $P$. maculatus on a large scale, covering the tropical Brazilian continental shelf. Goatfishes in general are important species, not only as an economic resource but also because of their ecological role. As they are nuclear species, their importance in trophic webs goes beyond what they eat. The spotted goatfish is a key species in many interspecific relations, and is commonly reported to interact with endangered species such as Sparisoma axillare and Sparisoma frondosum, providing food for them as a consequence of their foraging activity (Krajewski et al. 2006, Sazima et al. 2006, 2007).

\section{Distribution patterns}

Munro (1976) affirms that there are no migratory movements of $P$. maculatus, which means they do not move far from the areas in which they settle. In our study, juveniles were found well distributed along the continental shelf, including in areas near the shelf break, but a slight difference in size distribution was noted, mainly due to the fact that larger individuals seemed to be more related to water that is deeper and further from coastal areas. Fishing pressure is concentrated near the coast (Lessa et al. 2004) and might play a role in the aforementioned pattern by removing larger individuals from the coastal areas.

The CPUE patterns indicated that $P$. maculatus is more abundant in the area below $8^{\circ} \mathrm{S}$, but that it also had relatively higher abundance in Northern Pernambuco and in Southern Paraíba, where the largest fishery fleet that targets the spotted goatfish is located (Lessa et al. 2004, Ribeiro 2004). The analysis of the size distribution indicated that most juveniles were found in SWCR habitats, mainly in the southern areas. The higher CPUE values may be due to the presence of a great extension of coral reefs in this region (Costa et al. 2007, Leão et al. 2016) and the fact that most of this area is included in two MPAs (APA Costa dos Corais and APA Guadalupe) (Floeter et al. 2007, Steiner et al. 2015, Eduardo et al. 2018). Furthermore, upwelling processes have been reported in these areas, in which nutrients are transferred from deep to shallow layers, and this is linked to a higher abundance of prey for fish assemblages (MMA 2006). Some studies have reported that fishing activity affects marine ecosystems by modifying habitats and depleting fish populations, consequently altering their structures and affecting fish abundance (Garcia et al. 2003, Worm et al. 2006, Kenchington 2003). Therefore, MPAs are critical to the conservation and sustainable use of marine resources because they protect reproductive, nursery and feeding areas.

\section{Population aspects}

According to Lessa et al. (2004), length-frequency distribution does not change over the year and recruitment occurs mainly between March and September. The modal class (16-18 cm SL) was slightly lower than that reported by Lessa et al. (2004) (18-20 cm SL). These factors could be explained by several factors, such as fishing pressure over time and spatial-temporal contrasts, although both are unlikely causes. Instead, we assumed that the main cause is differences in gear selectivity, because our specimens were caught using bottom trawling, whereas Lessa et al. (2004) used trap fishing samples from commercial catches.

Adult individuals of $P$. maculatus are usually present in deeper areas with a muddy or sandy substratum available for foraging activity, while juveniles occupy seagrass bed areas (Munro 1976). Krajewski et al. (2006) also observed a high frequency of $P$. maculatus in areas of mixed substratum composed of algae, sand and coral reef, but they were also present foraging over substrata other than sand. In this study, $P$. maculatus displayed a similar pattern, occupying all types of habitat.

The condition factor $(K)$ showed different values between habitats and latitude levels, with individuals from SWCR and stratum D showing smaller values. However, these differences seem to be more related to the fact that individuals caught in this area came mostly from the first ABRACOS campaign, which occurred in August-September 2015. Fish from the second campaign (April-May of 2017) were caught during the reproductive season of the spotted goatfish (Munro 1983, Santana et al. 2006), which can explain the higher K values for specimens with mature gonads caught during this campaign than during the first campaign.

The obtained length at first maturity $\left(\mathrm{L}_{50}\right)$ differed from that of Santana et al. (2006), based on Munro (1976), which estimated the age corresponding to the $\mathrm{L}_{50}$ through the inverted Von Bertalanffy growth. Munro (1976) suggested P. maculatus reach maturity size at a minimum of $16 \mathrm{~cm}$ SL, a value somewhat higher than what we found. This discrepancy could be a result of differences between sampling, since our samples covered a broad range of lengths in different areas. Also, the reduced $\mathrm{L}_{50}$ might be a reflection of fishing pressure. The official statistics of Brazil state that there was a marked increase in the landings of $P$. maculatus, from $18 \mathrm{t}$ in 1994 to $296 \mathrm{t}$ in 2007 (IBAMA 2008), with a peak of $626 \mathrm{t}$ in 2000 (IBAMA 2002). Intense fishing pressure may affect growth and maturity of fish, with those species prone to high fishing mortality rates maturing early (Olsen et al. 2004, Green 2008, Tsikliras and Stergiou 2014). Since 2007, there have been no official reports and no studies about stock assessment, so we do not know the exact current state of the stocks. Nevertheless, Lessa (2004) warned that these fish populations have already been impacted by the removal of immature specimens, compromising the state of these stocks. 
Males were significantly larger than females and were more frequent in larger size classes. Sexual dimorphism has been reported previously, with males being larger and having "higher arched backs and more angular facial profiles", while females are more fusiform with a more hydrodynamic shape (Caldwell 1962, Munro 1976). Our LWR results differed from those obtained by Campos and Oliveira (2001), but they only had specimens above $\mathrm{L}_{50}$, lacking smaller individuals. Also, their study area was restricted to regions explored by the artisanal fleet of North Pernambuco. Similar results were found by Munro (1983), with females showing negative allometric growth, confirming Caldwell's (1962) observations that males and females of $P$. maculatus have sexual dimorphism.

\section{Feeding habits and diet}

Feeding activity of $P$. maculatus was classified as diurnal, since most individuals caught nocturnally had low or no food contents in their guts, which confirms previous results (Bohlke and Chaplin 1968, Munro 1976, 1983). The feeding intensity described by the FI can be influenced by the availability and type of prey, body length and season (Shanti Prabha and Manjulatha 2010, Mondal and Mitra 2016, Perelman et al. 2017). In general, the FI did not vary between habitats and shelf positions, but was higher in the southern areas, where the marine protected area APA Costa dos Corais is located. An MPA may provide high diversity of habitat and abundance of prey (Bonaldo et al. 2017, Novaczek et al. 2017), which may result in higher feeding success.

The presence of several epibenthic organisms in the diet of $P$. maculatus, such as decapods, polychaetes and amphipods, suggests that it is a generalist predator specialized in zoobenthos. Krajewski et al. (2006) described the feeding behaviour of $P$. maculatus as skimming the sea bottom with its barbels before shovelling and turning over the substratum to seek its prey. As described by several authors (Gosline 1984, Krajewski et al. 2006, Sazima et al. 2010), the spotted goatfish plays an important role in the benthic ecosystem by disturbing the substratum, changing the bottom topography and the distribution of benthic organisms and then attracting other carnivorous fishes that prey on the small organisms flushed out during the substratum disturbance.

The highest spectrum of prey was seen within the SWCR habitats and the lowest in algal turfs. Though there was a higher spectrum of prey in SWCR habitats, the niche breadth was smaller than that in the other habitats, suggesting a possible preference for a specific prey in this habitat or a possible low abundance of prey in the algae habitat, forcing the individuals in this substratum to widen the range of its prey. The diet of $P$. maculatus was not significantly different between habitats, shelf positions or latitudes. Though the waters of the study area usually have a high diversity and abundance of prey (CBD 2014, Eduardo et al. 2018), $P$. maculatus feeds mostly on crustaceans (shrimps, Brachyura, Stomatopoda) and, more rarely but still importantly, on Polychaeta and teleosts. No clear $\delta^{13} \mathrm{C}$ and $\delta^{15} \mathrm{~N}$ patterns between either habitats or positions along the shelf were found for P. maculatus. Small differences between latitude strata were observed, although these were biologically irrelevant (less than $1 \%$ o). While other studies reported a possible positive relationship between $\delta^{15} \mathrm{~N}$ and growth (Kolasinski et al. 2009), no relationship was found between $\delta^{15} \mathrm{~N}$ and body size, possibly due to the size-specialized bottom-foraging feeding mode of $P$. maculatus. The trophic positions estimated with stable isotope analysis showed that $P$. maculatus is ranked between the third and fourth trophic level. These results are endorsed by previous studies based on stomach content analysis for P. maculatus (Randall 1967, Sierra et al. 1994, GómezCanchong et al. 2004) and for other species of the family Mullidae (Hobson 1974, Golani 1994, Kulbicki et al. 2005). A similar estimation of the mean trophic position was obtained from our stomach content analysis, suggesting stability in the feeding habits of P. maculatus during its lifetime. Indeed, this species seems to be capable of maintaining a constant diet as it is a very specialized feeder with sophisticated chemo-sensorial barbels that allow it to search and retrieve its prey in the substratum (Krajewski et al. 2006).

The results of the present work provide information about the distribution of the spotted goatfish and its trophic relations among different habitats and locations. Dietary analysis is a particularly important tool for comprehending aspects of biology and ecology, especially when allied with spatial marine planning aimed at sustainable management of fishing stocks and the development of conservation measures (La Mesa et al. 2007, Kitsos et al. 2008). In fact, our results endorse Eduardo et al. (2018), who identified several potential areas for implementation of MPAs, contributing to future management and conservation measures for this species.

\section{ACKNOWLEDGEMENTS}

We thank the French oceanographic fleet and IRD for funding the surveys, as well as the crew of the R/V Antea for their essential contribution to the success of this project. This study was partially sponsored by CAPES (Coordination for the Improvement of Higher Education Personnel) though a scholarship granted to Andrey Soares and the National Council for Scientific and Technological Development (CNPq), through a productivity research grant to Beatrice Padovani Ferreira, Flávia Lucena Frédou (CNPq n³05014/2016-1) and Thierry Frédou (CNPq n⿳312211/2017-1). This work is a contribution to LMI TAPIOCA, programme CAPES/COFECUB (88881.142689/2017-01), and the PADDLE project, which has received funding from the European Union's Horizon 2020 research and innovation programme under grant agreement No 73427. Additionally, this work includes the ILTER site 18 PELD-TAMS/CNPq.

\section{REFERENCES}

Adams S.M., Kimmel B.L., Ploskey G.R. 1983. Sources of Organic Matter for Reservoir Fish Production: A Trophic-Dynamics Analysis. Can. J. Fish. Aquat. Sci. 40: 1480-1495. 
https://doi.org/10.1139/f83-170

Albieri R.J., Araújo F.G. 2010. Reproductive biology of the mullet Mugil liza (Teleostei: Mugilidae) in a tropical Brazilian bay. Soc. Bras. Zool. 27: 331-340. https://doi.org/10.1590/S1984-46702010000300003

Amundsen P.A., Gabler H.M., Staldvik F.J. 1996. A new approach to graphical analysis of feeding strategy from stomach contents data - modification of the Costello (1990) method. J. Fish Biol. 48: 607-614.

https://doi.org/10.1111/j.1095-8649.1996.tb01455.x

Bertrand A. 2015. ABRACOS Cruise, R/V Antea. https://doi.org/10.17600/15005600

Bertrand A. 2017. ABRACOS 2 Cruise, R/V Antea. https://doi.org/10.17600/17004100

Bohlke J.E., Chaplin C.C. 1968. Fishes of the Bahamas and Adjacent Tropical Waters. University of Texas Press, Texas.

Bonaldo R.M., Pires M.M., Guimarães P.R., et al. 2017. Small Marine Protected Areas in Fiji Provide Refuge for Reef Fish Assemblages, Feeding Groups, and Corals. PLoS One 12: e0170638 https://doi.org/10.1371/journal.pone.0170638

Bowen S. 1996. Quantitative Description of the Diet. In: Murphy D.R, Willis D.W. (eds) Fisheries Techniques, American Fisheries Society, Bethesda, MD, pp. 513-532.

Caldwell M.C. 1962. Development and Distribution of Larval and Juvenile Fishes of the Family Mullidae of the Western North Atlantic. Fish. Bull. Fish Wildl. Serv. 62: 403-456. https://doi.org/10.2307/1440910

Campos C.E.C., Oliveira J.E.L. 2001. Caracterização Biométrica e Merística Do Saramunete, Pseudupeneus maculatus (Osteichthyes:Mullidae), Em Ponta de Pedras, Pernambuco. Bol. do Inst. Pesca São Paulo 27: 185-189.

Convention on Biological Diversity (CBD). 2014. Ecologically or Biologically Significant Marine Areas (EBSAs). Special Places in the World's Oceans. 2nd edition. Recife.

Clarke K.R. 1993. Non-parametric multivariate analyses of changes in community structure. Aust. J. Ecol. 18: 117-143. https://doi.org/10.1111/j.1442-9993.1993.tb00438.x

Costa P.A.S., Olavo G., Martins A.S. 2007. Biodiversidade Da Fauna Marinha Profunda Na Costa Central Brasileira. Rio de Janeiro.

Costello M.J. 1990. Predator feeding strategy and prey importance: a new graphical analysis. J. Fish Biol. 36: 261-263. https://doi.org/10.1111/j.1095-8649.1990.tb05601.x

Douvere F., Ehler C.N. 2009. New perspectives on sea use management: initial findings from European experience with marine spatial planning. J. Environ. Manage. 90: 77-88. https://doi.org/10.1016/j.jenvman.2008.07.004

Eduardo L.N., Frédou T., Lira A.S., et al. 2018. Identifying key habitat and spatial patterns of fish biodiversity in the tropical Brazilian continental shelf. Cont. Shelf Res. 166: 108-118. https://doi.org/10.1016/j.csr.2018.07.002

Ehler C. 2013. Pan-Arctic Marine Spatial Planning: An Idea Whose Time Has Come. In: Tedsen E., Cavalieri S., et al. (eds), Arctic Marine Governance: Opportunities for Transatlantic Cooperation, Springer, Berlin, Heidelberg, pp. 199-213. https://doi.org/10.1007/978-3-642-38595-7 9

Ehler C., Zaucha J., Gee K. 2019. Maritime/Marine Spatial Planning at the Interface of Research and Practice: Past, Present and Future. In: Zaucha J., Gee K. (eds), Maritime Spatial Planning, Palgrave Macmillan, Cham, pp. 1-21. https://doi.org/10.1007/978-3-319-98696-8_1

Ferreira B.P., Maida M. 2007. Characteristics and Perspectives for Fishery Management in the Coral Coast Marine Protected Area. In: Prates A.P., Blanc D., Aquatic Protected Areas as Fisheries Management Tools. Empório das Letras, Brasília-MMA/ SBF, pp. 39-63.

Filkovsky G., Springer J.T. 2010. Interactive Use of Barbels by Spotted Goatfish Pseudupeneus maculatus (Bloch, 1793) on the Reef of Bonaire, Lesser Antilles. Open Mar. Biol. J. 4: 122-124. https://doi.org/10.2174/1874450801004010122

Floeter S., Ferreira C., Gasparini J. 2007. Os Efeitos Da Pesca e Da Proteção Através de UC's Marinhas: Três Estudos de Caso e Implicações Para Os Grupos Funcionais de Peixes Recifais No Brasil. Áreas Aquáticas Protegidas como Instrum. Gestão Pesqueira (Brasil. Minnistério do Meio Ambient. org.). MMA, Brasília 4: 183-199.

Fry B. 1988. Food web structure on Georges Bank from stable C, N and $\mathrm{S}$ isotopic compositions. Am. Soc. Limnol. Oceanogr. 33: 1182-1190. https://doi.org/10.4319/1o.1988.33.5.1182

Garcia S.M. Zerbi A. Aliaume C., et al 2003. The Ecosystem Approach to Fisheries. Issues, Terminology, Principles, Institutional Foundations, Implementation and Outlook. FAO, Rome. FAO Fish. Tech. Paper 443.

Golani D. 1994. Niche separation between colonizing and indigenous goatfishes (Mullidae) along the Mediterranean coast of Israel. J. Fish Biol. 45: 503-513. https://doi.org/10.1111/j.1095-8649.1994.tb01332.x

Gómez-Canchong P., Manjarrés L.M., Duarte L.O., et al. 2004. Atlas Pesquero Del Area Norte Del Mar Caribe de Colombia, Universidad del Magadalena, Santa Marta.

Gosline W.A. 1984. Structure, Function, and Ecology in the Goatfishes (Family Mullidae). Pacific Sci. 38: 312-323.

Green B.S. 2008. Chapter 1 Maternal Effects in Fish Populations. Adv. Mar. Biol. 54: 1-105. https://doi.org/10.1016/S0065-2881(08)00001-1

Hobson E.S. 1974. Feeding Relationship of Teleostean Fishes on Coral Reefs in Kona, Hawaii. Fish. Bull. 72: 915-1031.

Hyslop E.J. 1980. Stomach contents analysis-a review of methods and their application. J. Fish Biol. 17: 411-429. https://doi.org/10.1111/j.1095-8649.1980.tb02775.x

Instituto Brasileiro do Meio Ambiente e dos Recursos Naturais Renováveis (IBAMA). 2002. Estatística Da Pesca 2000 Brasil: Grandes Regiões e Unidades Da Federação, IBAMA ed. Tamandaré.

Instituto Brasileiro do Meio Ambiente e dos Recursos Naturais Renováveis (IBAMA). 2008. Estatística Da Pesca 2006 Brasil: Grandes Regiões e Unidades Da Federação, IBAMA ed., Brasília.

Kawakami E., Vazzoler G. 1980. Método gráfico e estimatica de índice alimentar aplicado no estudo de alimentação de peixes. Bol. do Inst. Ocean. 29: 205-207. https://doi.org/10.1590/S0373-55241980000200043

Kenchington E.L. 2003. The effects of fishing on species and genetic diversity. In: Sinclair M., Valdimarsson G. (eds), Responsible fisheries in the marine ecosystem. CABI Publ., Wallingford, pp. 235-253. https://doi.org/10.1079/9780851996332.0235

King M. 2007. Fisheries Biology, Assessment and Management, 2nd ed., Blackwell Publishing, Oxford, UK. https://doi.org/10.1002/9781118688038

Kitsos M.S., Tzomos T., Anagnostopoulou L., et al. 2008. Diet composition of the seahorses, Hippocampus guttulatus Cuvier, 1829 and Hippocampus hippocampus (L., 1758) (Teleostei, Syngnathidae) in the Aegean Sea. J. Fish Biol. 72: 1259-1267. https://doi.org/10.1111/j.1095-8649.2007.01789.x

Kolasinski J., Frouin P., Sallon A., et al. 2009. Feeding ecology and ontogenetic dietary shift of yellowstripe goatfish Mulloidichthys flavolineatus (Mullidae) at Reunion Island, SW Indian Ocean. Mar. Ecol. Prog. Ser. 386: 181-195. https://doi.org/10.3354/meps08081

Krajewski J.P., Bonaldo R.M., Sazima C., et al. 2006. Foraging activity and behaviour of two goatfish species (Perciformes: Mullidae) at Fernando de Noronha Archipelago, tropical West Atlantic. Environ. Biol. Fishes 77: 1-8. https://doi.org/10.1007/s10641-006-9046-z

Kulbicki M., Bozec Y.-M., Labrosse P., et al. 2005. Diet composition of carnivorous fishes from coral reef lagoons of New Caledonia. Aquat. Living Resour. 18: 231-250. https://doi.org/10.1051/alr:2005029

La Mesa G., La Mesa M., Tomassetti P. 2007. Feeding habits of the Madeira rockfish Scorpaena maderensis from central Mediterranean Sea. Mar. Biol. 150: 1313-1320. https://doi.org/10.1007/s00227-006-0414-1

Leão Z.M.A.N., Kikuchi R.K.P., Ferreira B.P., et al. 2016. Brazilian coral reefs in a period of global change: A synthesis. Brazilian J. Oceanogr. 64: 97-116. https://doi.org/10.1590/S1679-875920160916064sp2

Lessa R.P., Nóbrega M., Bezerra Júnior J.L. 2004. Dinâmica de Populações e Avaliação de Estoques dos Recursos Pesqueiros da Região Nordeste. Ministério do Meio Ambiente, Recife.

Levins R. 1968. Evolution in Changing Environments: Some Theoretical Explorations. Princeton University Press, Princeton.

Marques S., Ferreira B.P. 2010. Composição e Características Da Pesca de Armadilhas No Litoral Norte de Pernambuco - Brasil. Bol. Técnico Cient. do CEPENE 18: 49-60.

Ministerio do Meio Ambiente (MMA). 2006. Programa REVIZEE. Avaliação Do Potencial Sustentavel de Recursos Vivos Na Zona Economica Exclusiva. Ministerio do Meio Ambiente, 
Brasilia - DF.

Mondal A., Mitra A. 2016. Growth, Food and Feeding Habit with Prey Preference of Long Whiskered Catfish, Mystus gulio ( Hamilton, 1822 ) in Brackishwater Traditional Impoundments of Sundarban, India. Int. J. Fish. Aquat. Stud. 4: 49-58.

Munro J.L. 1976. Aspects of the biology and ecology of Caribbean reef fishes: Mullidae (goat-fishes). J. Fish Biol. 9: 79-97. https://doi.org/10.1111/j.1095-8649.1976.tb04664.x

Munro J.L. 1983. Epilogue: Progress in Coral Reef Fisheries Research: 1973-1982. In: Munro J.L. (ed.), Carribean Coral Reef Fishery Ressources, ICLARM Studies and Review, Manilla, Phillipines, pp. 249-265.

Novaczek E., Howse V., Pretty C., et al. 2017. Limited Contribution of Small Marine Protected Areas to Regional Biodiversity: The Example of a Small Canadian No-Take MPA. Front. Mar. Sci. 4: 174 . https://doi.org/10.3389/fmars.2017.00174

Oksanen J., Blanchet F.G., Friendly M., et al. 2019. Vegan: Community Ecology Package.

Oliveira A.K., Alvim M.C., Peret A.C., et al. 2004. Diet shifts related to body size of the Pirambeba Serrasalmus brandtii Lütken, 1875 (Osteichthyes, Serrasalminae) in the Cajuru Reservoir, São Francisco River Basin, Brazil. Brazilian J. Biol. 64: $117-124$. https://doi.org/10.1590/S1519-69842004000100013

Olsen E.M., Heino M., Lilly G.R., et al. 2004. Maturation trends indicative of rapid evolution preceded the collapse of northern cod. Nature 428: 932-935. https://doi.org/10.1038/nature02430

Perelman J.N., Schmidt K.N., Haro I., et al. 2017. Feeding dynamics, consumption rates and daily ration of wahoo Acanthocybium solandri in Indo-Pacific waters. J. Fish Biol. 90: 1842-1860. https://doi.org/10.1111/jfb. 13270

Pinkas L., Oliphant M.S., Iverson I.L.K. 1971. Food Habits of Albacore, Bluefin Tuna, and Bonito In California Waters. Calif. Dep. Fish Game, Fish Bull. 152

Post D.M. 2002. Using Stable Isotopes to Estimate Trophic Postition: Models, Methods and Assumptions. Ecology 83: 703-718. https://doi.org/10.1890/0012-9658(2002)083[0703:USITET]2. 0.CO;2

Prates A.P.L., Cordeiro A.Z., Ferreira B.P., Maida M. 2007. Coastal and Marine Sustainable Use Protected Areas as Tools for Fisheries Management. In: Prates A., Blanc D., Aquatic Protected Areas as Fisheries Management Tools. Empório das Letras, Brasília-MMA/ SBF, pp. 25-37.

R Core Team. 2019. R: A Language and Environment for Statistical Computing. R Foundation for Statistical Computing, Vienna.

Randall J.E. 1967. Food Habits of Reef Fishes of the West Indies Food Habits of Reef Fishes Of The West. Stud. Trop. Oceanogr. 5: 665-847.

Ribeiro F.P. 2004. Composição Da Biocenose e Abundância Relativa de Peixes Capturados Com Covos Nos Estados Do Rio Grande Do Norte e Pernambuco (Brasil). Bol. Técnico Cient. do CEPENE 12: 113-128.

Ricker W.E. 1975. Computation and Interpretation of Biological Statistics of Fish Population. Bull. Fish. Res. Board Canada
191: 1-382.

Santana F.M., Morize E., Lessa R. 2006. Age and growth of the spotted goatfish, Pseudupeneus maculatus (Bloch, 1793) in Brazil, validated through marginal increment and oxytetracycline dyes in the sagittae. J. Appl. Ichthyol. 22: 132-137. https://doi.org/10.1111/j.1439-0426.2006.00724.x

Sazima C., Krajewski J.P., Bonaldo R.M., et al. 2006. The goatfish Pseudupeneus maculatus and its follower fishes at an oceanic island in the tropical west Atlantic. J. Fish Biol. 69: 883-891. https://doi.org/10.1111/j.1095-8649.2006.01166.x

Sazima C., Krajewski J.P., Bonaldo R.M., et al. 2007. Nuclearfollower foraging associations of reef fishes and other animals at an oceanic archipelago. Environ. Biol. Fishes 80: 351-361. https://doi.org/10.1007/s10641-006-9123-3

Sazima C., Krajewski J.P., Roberta B., et al. 2010. Associações Alimentares Do Tipo Nuclear-Seguidor Entre Peixes e Outros Animais Em Fernando de Noronha. Bol. Soc. Bras. Ictiol. 100: 45-48.

Shanti Prabha Y., Manjulatha C. 2010. Food and Feeding Habits of Upeneus vittatus (Forsskal, 1775) from Visakhapatnam Coast (Andhra Pradesh) of India. Int. J. Zool. Res. 6: 351-355.

Sierra L.M., Claro R., Popov O.A. 1994. Alimentacion y Relaciones Tróficas. In: Claro R. (ed.), Ecología de los Peces Marinos de Cuba. Instituto de Oceanología Academia de Ciencias de Cuba and Centro de Investigaciones de Quintana Roo, Mexico, pp. 263-284.

Steiner A.Q., Amaral F.M.D., Amaral J.R.de B.C.do, et al. 2015. Zonação de recifes emersos da Área de Proteção Ambiental Costa dos Corais, Nordeste do Brasil. Iheringia. Série Zool. 105: $184-192$. https://doi.org/10.1590/1678-476620151052184192

Tsikliras A.C., Stergiou K.I. 2014. Size at maturity of Mediterranean marine fishes. Rev. Fish Biol. Fish. 24: 219-268. https://doi.org/10.1007/s11160-013-9330-x

Vanderklift M.A., Ponsard S. 2003. Sources of variation in consumer-diet $\triangle 15 \mathrm{~N}$ enrichment: a meta-analysis. Oecologia 136: 169-182. https://doi.org/10.1007/s00442-003-1270-z

Vazzoler A.E.A. 1996. Biologia da reprodução de peixes teleósteos: Teoria e prática. Eduem/SBI/CNPq/Nupelia, Maringá.

Viana A.P., Lucena Frédou F., Frédou T., et al. 2010. Fish fauna as an indicator of environmental quality in an urbanised region of the Amazon estuary. J. Fish Biol. 76: 467-486. https://doi.org/10.1111/j.1095-8649.2009.02487.x

Vital H., Gomes M.P., Tabosa W.F., et al. 2010. Characterization of the Brazilian continental shelf adjacent to Rio Grande do Norte state, NE Brazil. Brazilian J. Oceanogr. 58: 43-54. https://doi.org/10.1590/S1679-87592010000500005

Worm B., Barbier E.B., Beaumont N., et al. 2006. Impacts of Biodiversity Loss on Ocean Ecosystem Services. Science 314: 787-790. https://doi.org/10.1126/science.1132294

Zavala-Camin L.A. 1996. Introducão aos estudos sobre alimentaç̃o natural em peixes, 1st ed.: Editora da Universidade Estadual de Maringá, Maringá. 